\title{
The Impact of Audit Committee Performance and Composition on Financial Reporting Quality in Jordan
}

\author{
Qasim Ahmad Alawaqleh ${ }^{1} \&$ Nashat Ali Almasria ${ }^{1}$ \\ ${ }^{1}$ Accounting Department, Philadelphia University, Jordan \\ Correspondence: Qasim Ahmad Alawaqleh, Accounting Department, Philadelphia University, Jordan. E-mail: \\ nalmasria@philadelphia.edu.jo
}

Received: December 11, 2020

Accepted: December 28, 2020

Online Published: January 11, 2021

doi:10.5430/ijfr.v12n3p55

URL: https://doi.org/10.5430/ijfr.v12n3p55

\begin{abstract}
The corporate governance literature indicates efforts to investigate the role of the audit committee (AC) in improving the financial reporting quality (FRQ) after the emergence of financial scandals in many countries in the world, inclusive Jordan. To date, empirical findings are inconclusive enough to address all audit committee characteristics regarding its competency and responsibilities by employing a questionnaire to collect data about this relationship. Thus, this study measures the correlation between AC (performance and composition) and FRQ of manufacturing corporations registered on the Amman Stock Exchange (ASE). To test this impact empirically, the target population was financial managers, audit committee members, and internal audit managers who are working in manufacturing corporations listed on the (ASE). According to the coefficient ( $\beta$ ), the independent variables (Audit Committee Performance and Audit Committee Composition influence the dependent variable FRQ. This research recommends that firms enhance the audit committee work performance and composition to ensure audit committee members effectively enhance the FRQ audit committee is a vital mechanism of the firm's corporate governance system.
\end{abstract}

Keywords: audit committee, financial reporting quality, ASE, Jordan, audit committee performance, audit committee composition

\section{Introduction}

Financial reports must be treated with a certain amount of caution by companies as some of the economic content provided may be ambiguous and materially false (Cohen et al., 2017). When information included in a financial report is proven to be erroneous, this may create a challenging situation for a company besides its regulator and its auditors, resulting in insolvency in addition to legal action (Bajra and Čadež, 2018). Concerning manufacturing firms registered on the (ASE) in Jordan, the financial report is a vital source of invaluable information, seeing as stakeholders can employ it to make sensible decisions regarding future investments and fund commitments. Financial statements can be used to evaluate both the current and past performance of a company regarding its past performance concerning other companies operating within the same sector and throughout the entire economy. It is worth mentioning that other sources of financial information are freely available regarding manufacturing companies recorded on the (ASE). Nevertheless, financial reports are acknowledged as comprising data that is more credible and essential.

The previous literature indicate efforts to address some aspects of the relationship between (AC) and (FRQ), for instance, Al-Shaer, et al., (2017), highlighted well-known episodes of impropriety relating to corporations, such as WorldCom, a telecommunications company and Enron, services, and commodities company in the US, along with Cadbury, Intercontinental Bank PLC and Afribank in Nigeria, implicated widespread fraudulence and the misrepresentation of the contents contained within financial statements. Concerning preventing dishonesty regarding financial statements, companies act in various ways, including establishing committees whose roles consist of scrutinizing the contents of financial reports from when they are being put together through to publication. Such a committee is termed the 'audit committee.' Eyenubo, Mudzamir, and Ali (2017), state that the audit committee contains various members of an organization responsible for supervising a company's accounting and financial reporting (FR) as part of the corporate governance (CG) tool, which improves the reliability of (FR). In his research, Ramsay (2001) asserted that corporations create audit committees to enhance the standard of financial practices and earnings and strengthen financials of integrity. Nonetheless, Umobong and Ibanichuka (2017) claim that committees of audit in Nigeria have failed to demonstrate the ability to conduct management duties, as shown in government 
agencies' mismanagement and various financial institutions' collapse. Thus, the audit committee value continues to be questioned by those involved in this particular sector. On the contrary, this research highlights that the audit committee is vitally vital in Jordan Because of the failure of many industrial companies in Jordan and the lack of early warning by the external auditor of the existence of financial difficulties. The researchers believe that it is essential to study the (ACs) vital role in improving (FRQ) and financial reports users' confidence.

Concerning Jordan, the (FRQ) of manufacturing firms intends to protect shareholders' investments and attract local and overseas investments (Alawaqleh, 2008). To achieve these objectives, audit committees help develop the quality of financial reports, prevent fraud, collapse, and increase confidence in financial reporting (Ababneh, 2012; Bekhet and Matar, 2013). In his research, Alawaqleh (2008) remarked that numerous Jordan companies had collapsed due to failings in their financial reports. They had not raised concerns regarding the credibility and any irregularities contained (Abdullah et al., 2008; Hor, 2008). It is also vital to note that various other studies confirmed that countless businesses worldwide had failed due to the failings connected with financial reports (Köhler and Quick, 2018). The value of financial reporting can be enhanced by employing supervising audit committees (Cohen et al., 2004). As governance regulations, such as the (JCGC) and (ISA), emphasize a definite want for enhancement to the quality of financial reporting. Likewise, many incidents have been reported owing to audit failure and weak governance practices (Ababneh, 2012). Each of these scandals and collapses were attributed to an inadequate governance system (Karaibrahimoglu, 2013; Beisland et al., 2015; Nigel and Ifedapo, 2018).

Furthermore, the degree to which irregularities in information are reduced via financial reports is primarily dependent on the quality and reliability of the financial reports. The Jordanian Corporate Governance Code concentrates on audit committees' value in guaranteeing financial statements (JCGC, 2006). To resolve this serious issue, the researchers created the following questions shown below:

1. Is there a statistically significant effect of (AC) performance on the (FRQ) in industrial firms registered on the (ASE)?

2. Is there a statistically significant effect composition of the (AC) on (FRQ) in industrial firms registered on the (ASE)?

This particular study contributes to the existing knowledge and practice in several distinctive ways, specifically by increasing the current theoretical and practical literature through establishing and analyzing the relationship between (AC) performance and composition, besides the (FRQ) in industrial companies registered on the (ASE).

The JCGC (2006) emphasized the audit committee role as principal monitoring mechanisms that guarantee superior (FRQ). It mentions that audit committees should have relevant qualifications in economics or accounting and accounting-related fields and experience to enhance the quality of discussions and their decisions (Sharar, 2006). Moreover, it is essential to state that the Code stresses the (AC) as the foundation of (CG) systems regarding developing financial reporting quality. The JCGC (2012) made specific recommendations concerning committee responsibilities, which guarantee financial reports and economic systems. These results in practice can increase the (FRQ) and consider the quality of control systems and methods applied in Jordanian manufacturing companies. Given the significance of financial reporting concerning increasing investor confidence and developing financial markets, this research will explore the audit committee's composition and function in the Jordanian market in guaranteeing financial reporting that is of exceptional quality.

This section has presented an overview of the background of the study phenomena. The rest of the article is structured as follows; the literature review and hypothesis development we developed in section 2 which enables evaluating and reviewing the available empirical evidence about the study hypothesis which are related to the studys' questions. The study methodology that has driven the research analysis was developed in section 3. Empirical findings was conducting in section 4 which allows testing the hypothesis and offering further support from analysis regarding the study hypothesis. In addition, the paper highlighted the suggestions for future research of the study and the justification and value for conducting this study.

\section{Literature Review and Hypotheses}

\subsection{The Performance of the Audit Committee}

The board of directors establishes an (AC) primarily to observe the process of (FR) and deliver financial control regarding corporation economic events (Menon and Williams, 1994). Likewise, during the audit period, the (AC) is responsible for contacting, communicating, and cooperating with the external auditor (Carcello and Neal, 2000; Soliman and Ragab, 2014). Additionally, audit committees have responsibility for evaluating internal audit work and guaranteeing that the firm's management applies the internal audit (Ismail et al., 2016). 
The JCGC (2006) also emphasizes that it is essential that the audit committee should examine auditing actions and internal control; specifically considering the challenges associated with employing and firing auditors. Furthermore, the audit committee is responsible for evaluating and reviewing questions that pertain to the auditor's work, including the observations and evidence gathered by the auditors (Abbott and Parker, 2000).

The prior studies pointed out that corporations with efficient committees of audit, specifically independent of the members, are fewer likely to be hit by scandals (McMullen, 1996; Beasley et al., 2000; Vinten and Lee, 1993). They suggest that the (AC) ability and effectiveness have a crucial part in promoting the value of financial reporting systems. Furthermore, Goodwin and Seow (2000) claim that auditors confirm that an efficient (AC) also plays a valuable part in promoting (FRQ).

The JCGC (2006) asserts that all registered public corporations in Jordan should comprise a committee of the audit to reduce the clash of interest and to improve the amount of control regarding management actions. Agency theory states that most audit committee members should be independent managers (Jensen and Meckling, 1976).

Audit committees must assess the company's communication with external auditors (Alqatamin, 2018) Subsequently, give he board of directors invaluable feedback regarding their contact with auditors (Abbott and Parker, 2000). Additionally, pertinent information is crucial as it facilitates beneficial communication between the committee of the audit. This interaction between them would impact the monitoring process (JCGC, 2006; Cohen, 2002). Likewise, audit committees must perform a crucial part in assisting and improving monitoring, enhancing the external audit process, and preventing failure being reported (Lee et al., 2004; Turley and Zaman, 2004). Additionally, the (JCGC) underlines the importance of (ACs) consisting of independent members because they are unrestricted from the pressure of management. In their study, Carcello et al. (1992) considered the auditing standards to be the most critical factor in assisting audit committees to enhance audit procedures effectiveness.

The JCGC (2008) emphasized that the audit committee large in numbers, is based on different perceptions, which improves the accessibility of both the people and resources available (as more members on the (AC) allow the committee to be provided with better human resources) and offers more robust monitoring. Likewise, the JCGC (2008) stressed that it is essential that audit committees comprise members who have financial knowledge, besides the value of audit committees in select competent auditor and give recommendations to the board concerning their nomination. It added that audit committees must consider external auditor's approaches and carry out frequent reviews when audit work is being undertaken.

The vital role and responsibility of audit committees in the financial and monitoring process are demonstrated in the recent literature (Alqatamin, 2018; Alzoubi, 2019; Al-Hajaya, 2019; Nazari, and Soukhakyan, 2020). These studies recommend that audit committee performance promote and develop the FRQ by way of enhancing audit quality, internal monitoring systems and communication with external auditors (Alkilani and Hussin, 2019; Shatnawi, and Eldaia, 2019).

Within the reviewed literature, Kamel and Elkhatib (2013) explain developing markets in their empirical investigation undertaken in Egypt. The results obtained show that 'reviewing significant changes in accounting policies' is the most significant role for useful (ACs). The results also disclosed that most study samples believe that the audit committees experience in financial procedures and members' independence of the audit committee should be assessed when members are being selected.

DeZoort (1997) explores the views of (ACs) of their supervisory role within organizations. The findings show that audit committees perceive their part in internal control as one of the central monitoring mechanisms. It is essential to mention that DeZoort's conclusions illustrate that most audit committee members in the US believe that they lack the necessary expertise to supervise accounting and auditing practices. They also confirm that it is fundamental to get the experience to perform their role correctly. The results of their research also indicate that audit committee members undertake several functions along with those identified in the Corporate Governance Code, as a result, increases their supervision responsibilities. Likewise, DeZoort (1997) confirms that (ACs) value the assessment of internal controls more and consider it one of the most critical roles they must perform; this concurs with the legislation that audit committees must adhere to regarding monitoring and assessing internal control systems. DeZoort's research paper also explains that audit committees complete other essential tasks, such as evaluating financial statements and auditor gauging the utility. Nevertheless, it was stated that audit committees believe the opinion that was establishing auditor fees and assessing special economic events were not seen as being meaningful.

In the study they completed, Beattie et al. (2013) explore the opinions of audit partners, (AC) members, and financial officers to ascertain how economic and regulatory variables contribute to improving audit quality. These participants 
were asked to evaluate various audit committee factors and their impact on (FRQ), with auditors among the most vital aspects that enhance the quality of audit. The people interviewed emphasized the part of the audit committee in guaranteeing high audit quality. Based on the above dissection, the researchers formulated the following hypothesis:

H1: there is a statistically significant influence of the audit committee performance on (FRQ) in industrial corporations registered on the (ASE).

\subsection{Composition of the Audit Committee}

Ayinde (2002) maintains that the (AC) is a permanent committee created to improve firm responsibility by working in conjunction with management and internal auditors to develop a company's accounting and (FR) practices and safeguard the behaviour of companies' affairs in maintaining accepted ethical and legal standards. Likewise, influential (ACs) help reduce mistakes and promote regulatory compliance, internal control systems, and boosted voluntary disclosures.

Regarding quoted companies, the Security Exchange Commission further enhances the audit committee elements by stipulating the addition of non-executive board members. This particular structure aims to make sure that administration and stockholders are satisfactorily characterized in (ACs) seeing the crucial part they undertake and where administration should safeguard the owners' interests by guaranteeing that released (FRs) are a fair exemplification of the condition of a company. Kipkoech and Rono (2016) reveal that having experienced audit members enhanced quality monitoring and reduced financial misrepresentation. The conclusions also illustrated that experience and (AC) size considerably influence the corporation's performance. Moses, Ofurum, and Egbe (2016) showed insignificant impact concerning the (AC) size and the (FRQ) in Nigerian banks. Umobong and Ibanichuka (2017) analyzed the correlation between (AC) factors and the (FRQ) in relation to food and drink companies by utilizing secondary data was gathered from the Nigeria Stock Exchange. The results revealed a rise in members' financial experience of members, frequency of meetings, (AC) independence, and firm age increases (FRQ). The results also indicated that an increase in (AC) and company size reduces the (FRQ).

Onipe and Mohammed (2018) examine audit committee meetings and competencies on the (FRQ) to commercial banks in Nigeria. Data collected from fifteen commercial banks' financial statements in Nigeria from 2007 to 2016 implemented the modulate Jones (1991) model to measure the (FRQ). The outcomes confirmed that (AC) meetings have an insignificant positive effect on the value of (FR). Furthermore, (AC) knowledge had a negative influence on the importance of financing of the banks. This study created the following hypotheses:

$\mathrm{H}_{2}$ : There is a significant effect of (AC) composition on (FRQ) in industrial companies registered on the (ASE).

\section{Methodology}

\subsection{Measurement of Variables}

The purpose of this study is to empirically evaluate the influence of (AC) Performance and Composition on (FRQ). The questionnaire was designed to capture data about the study variables. The dependent and independent constructs are scaled on 5 points Likert scale to achieve the study objectives (Bryman and Bell, 2015; Hair et al., 2019). Earlier literature stresses the audit committee's impact in supporting the (FRQ) (Ghafran and O'Sullivan, 2013). In line with that, some studies employed primary data to evaluate this association, given that the questionnaire provides more trustworthy suggestions from secondary data (Contessotto and Moroney, 2014). Kamel and Elkhatib (2013) used a questionnaire to inspect various respondents, including financial managers, senior accountants, and external auditors, regarding committees and their possible impact (FRQ). Kipkoech and Rono (2016) seek to ascertain the effects of experience and size on Kenya companies' performance. To achieve that, the study used multiple regression for hypotheses tests. Moses, Ofurum, and Egbe (2016) studied the characteristics of 'audit committee on (FRQ) in Nigerian banks, the Jones model, and correlation was used. For measurement of independent variables, the (AC) role in the surveillance process over the (FR) was highlighted in the preceding practical evidence (Engel et al., 2010; Soliman and Ragab, 2014; Wu et al., 2016; Eng and Johansson, 2016). The measurement of composition and work performance of The (AC) was by using adapting and adopting items from the prior studies (Abbott and Parker, 2000; Cohen et al., 2013; Ghafran and O'sullivan, 2013) and confirmed by pertinent legislation (e.g., JCGC, 2006). These independent constructs are scaled on a 5 point Likert scale to achieve the study objectives (Bryman and Bell, 2015; Hair et al., 1998). Consequently, this study measured the composition of (ACs) based on qualified (AC) members, the qualifications of (AC) members, credibility, trustworthiness, integrity, independence, appropriate industry knowledge, participating in on-going education programs, compliance with (CG) regulations and guidelines, knowledge of company's financial reporting as well as accounting practices. This research measured (AC) 
performance by employing different indicators. The following are the measurements and items for measuring (AC) performance:

Scrutinize and evaluate internal control systems, examine and accept the company's financial and auditor reports review and approve types, a fess of non-audit service. Besides that, the external auditor chooses and dismissal makes contact with the external assessor concerning critical issues related to audits, considers and approves the extent of an audit plan with the external auditor, scrutinizes, and endorses the external auditor's estimate of control procedures. Furthermore, the external auditor independence, the audit committee reports, its proceedings, and proposals to the board after each committee meeting were also assessed by the researchers. On other hand, for measurement of financial reporting quality (D.V), the researchers relied on earlier studies as regards measuring the dependent variable. The main characteristics for measuring the financial reporting quality are relevancy, reliability, comparability, faithful representation, timeliness and understandability (Yurisandi and Puspitasari; 2015; Gaynor et. A;1. 2016; Biddle, at el 2009; Rainsbury, et. al (2009).

These dimensions were measured as following: Relevance correlates closely with materiality and usefulness. Relevance demonstrates the ability of users to make decisions. When the information provided within financial reports influences people's economic decisions, this information includes relevance quality. Similarly, when this information enables users to assess, correct, and corroborate both existing and prior events, it is beneficial. The value of making a decision an essential part of relevance is under the conceptual framework (Cheung et al., 2010). Applying Fair Value as the foundation for measurement is a sign of a superior degree of relevance regarding (FR) (Beest et al., 2009). It is essential to mention that annual reports have a critical part in establishing the degree of relevance by releasing information concerning opportunities of business and threats. It also offers guidance on how critical market happenings and importance transactions affect organizations and institutions (Beest, et al., 2009). Also, the reliability is a further essential aspect of FRQ. We assert that the information in financial reporting should be trustworthy to be effective, this can be achieved by delivering data that does not consist of material mistakes as well as bias. Reliability is analyzed founded on unbiased and confirmable qualities (Yurisandi and Puspitasari; 2015; Gaynor et. A;1. 2016).

In addition to that, Comparability permits users to assess financial statements to establish an organization's performance, financial position, and cash flow. Therefore, it enables users to determine among other companies in the same period and across time. To demonstrate this, (FRs) should reveal and clarify all the differences in accounting policies and the implications of these changes, let alone the consistency significant of employing accounting and principles. Likewise, results from the present accounting period can be contrasted with those found in earlier periods. Finally, the ratios and the presenting financial index numbers add to the comparison with other organizations (Beest et al., 2009).

Besides that, Understandability is an indispensable quality as regards financial reports information. Attaining the quality of understandability is via effective communication. As a result, the greater quality will be achieved by understanding the information provided by users (Cheung, et al., 2010). Understandability improvs the qualitative characteristics and will increase when the report is produced and ordered in a clear and straightforward way for users to follow (Beest, et al., 2009). Likewise, the use of tables and graphs presents information clearly, while the language used and technical jargon is relatively easy to understand. Then timeliness is an additional promotes qualitative features concerning financial information. Timeliness demonstrates that information should be obtainable to those who make decisions, given that the data should be available for the users promptly. Concerning annual reports, when considering the quality of reporting, timeliness is gauged by employing the period between the end of the year and the date of audit report issuing; more specifically, how many days the auditor required to put his/her signature on the information after the end of the financial year (Beest et al.,2009). The final dimension, faithful exemplification relates to the idea of demonstrating the real economic position of the financial data that has been declared by a company. This idea clarifies how well the commitments and economic events are entirely represented in (FR). Besides, this quality has neutrality, which relates to impartiality and stability as a sub notion. Willekens (2008), asserts that auditors' reports add significance to financial reporting evidence by delivering reassurances regarding the degree to which the yearly report accurately represents economic phenomena. Likewise, the annual report seeks to clarify statements and assessments and explain the use of the company's accounting principles in a simple way. Furthermore, faithful representation encompasses completeness, objectivity, and truthfulness, while it also stresses both the negative and positive changes and events by way of publishing them in the annual outcomes. Also, the unqualified opinion in the yearly report improves this quality. According to the previous framework posted by the (FASB), the reliability was one of the essential quality, which consists of exemplification faithfulness, verifiability and neutrality. Nevertheless, in the latest framework, faithful representation is the top quality, in preference to 
reliability. However, the FASB still believes that reliability is essential in relation to accounting information (Downen, 2014).

\subsection{Research Methodology and Data Collection}

The questionnaire was developed employing using the five point-Likert scale to describe the impact of audit committee performance and composition on (FRQ) in manufacturing companies listed on the (ASE). To ensure the questionnaire validity was utilized in this research, the researchers implemented pre-existing indicators from the existing literature. The researchers also forwarded the questionnaire to several experts (academics and external auditors) to confirm the questionnaire's reliability and appropriateness concerning the context (Polit-O'Hara and Beck, 2006). These experts offered valuable feedback, and as a consequence, revisions were made to the questionnaire. The pilot study analyzed the relationship between indicators and constructs concerning the questionnaire. Thereby, the questionnaire design was achieved after evaluating appropriate prior investigations and undertaking the pilot study with an audit committee. The questionnaire uses a Likert scale because there is equal space between the values of the scale. There are four primary levels: ratio, nominal, interval, and ordinal, for measuring the variables (Stevens, 1951). To understand this relationship, the target population was financial managers, audit committee members, and internal audit managers working in manufacturing companies listed on the Amman Stock Exchange in Jordan. Consequently, seeing as the population size is not too significant (approximately 354), this survey targeted each of them to conduct the empirical part of this research. This particular investigation used multiple regression analysis to ascertain the impact of (AC) performance and composition on the (FRQ) in manufacturing firms registered on the (ASE) (Hair et al., 2019). The researchers sent out 354 questionnaires to those wishing to participate. Of that number, 290 questionnaires were returned. However, 15 questionnaires were incomplete. Thus, 275 were employed for analysis purposes.

\section{Results}

\subsection{Descriptive Analysis}

Respondents to the sample study questionnaire were 41 financial managers by $0.15,177$ members of audit committees by 0.64 , and 57 internal audit managers by 0.21 .

\subsection{Data Analysis}

This research employed multiple regression analyses to identify the effect of (AC) performance and composition on (FRQ) in manufacturing companies listed on (ASE). (Hair et al.2019). The researchers distributed 354 questionnaires. The total Number of received questioners is 290; however, 15 questionnaires were incomplete; thus, the total number of the questionnaire used for analysis purposes 275.

\subsection{Study Model}

In light of the previous hypotheses, the study model consists of the independent variables represented by (AC) Performance and (AC) Composition. The dependent variable (FRQ) in manufacturing firms listed on (ASE).

The study model is based on the variables used in this study to explain and clarify (AC) Performance and (AC) Composition in (FRQ) in manufacturing firms listed on (ASE). Accordingly, the study model was designed as follows:

$$
\text { Independent Variables Dependent Variable }
$$

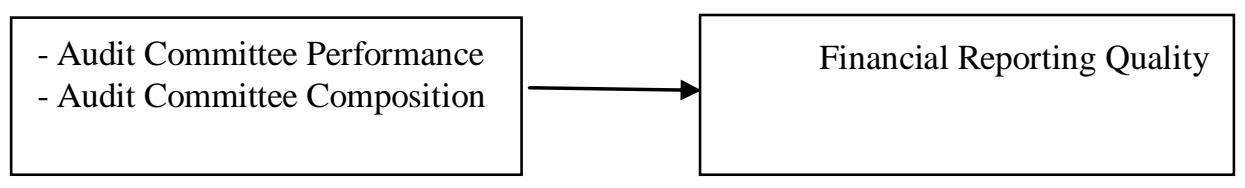

Figure 1. Research model

$\mathbf{Y}=\beta_{1} \mathrm{x}_{1}+\beta_{2} \mathrm{x}_{2}+\varepsilon$

Where

$\mathrm{Y}=$ financial reporting quality 
$\mathbf{x}_{1}=$ Audit Committee Performance

$\mathbf{x}_{\mathbf{2}}=$ Audit Committee Composition

$\varepsilon=$ Standard error

The regression coefficient $(\beta)$ indicates the influence of independent variables (Audit Committee Performance and Audit Committee Composition on the dependent variable (financial reporting quality). Since every single unit changes in the independent variable, $X$, the size of $\beta$ in the dependent variable $Y$ is expected to change. On the other hand, Statistical tests for the study instrument were used as Instrument Validity and Reliability. Whereas, Cronbach Alpha was as follows:

Table 1. Result of Cronbach Alpha

\begin{tabular}{lcc}
\hline Variables & Number of items & Cronbach Alpha \\
\hline Audit Committee Performance & 9 & 0.84 \\
Audit Committee Composition & 9 & 0.76 \\
financial reporting quality & 12 & 0.81 \\
\hline
\end{tabular}

Results were considered good stability for the study instrument because Cronbach Alpha results were more than 0.70 (Hair et al. 2019). Moreover, the researchers used the normality and linearity tests and the dispersion and variation in the sample responses (Homoscedasticity) after collecting the final data from the study sample. With regard to the normal distribution test, the researchers used the Bell distribution shape, looking at the normal distribution through the graph; we see that the normal distribution is free of Heteroscedasticity, In this respect, Statistical results also confirmed that there is a linearity relationship between (IVs) and (DV) in addition to dispersion and variation in the sample responses (Homoscedasticity) after collecting the final data from the study sample, these results shown in Figure 2,3and 4:

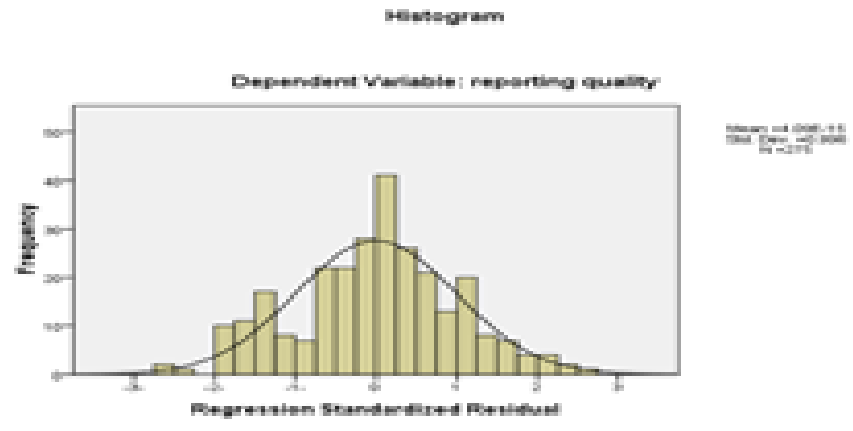

Figure 2. Result of normality

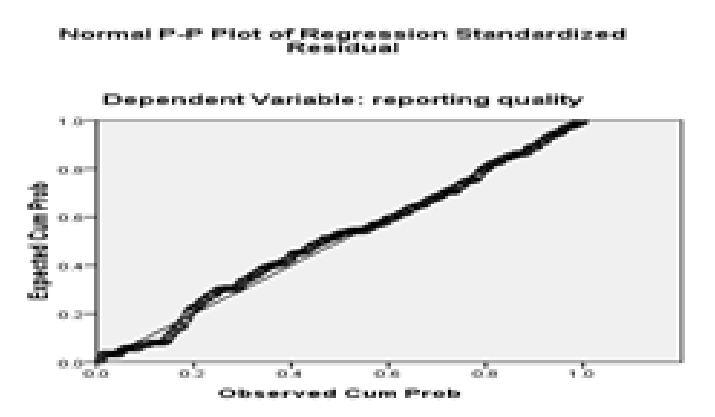

Figure 3. Result of linearity 


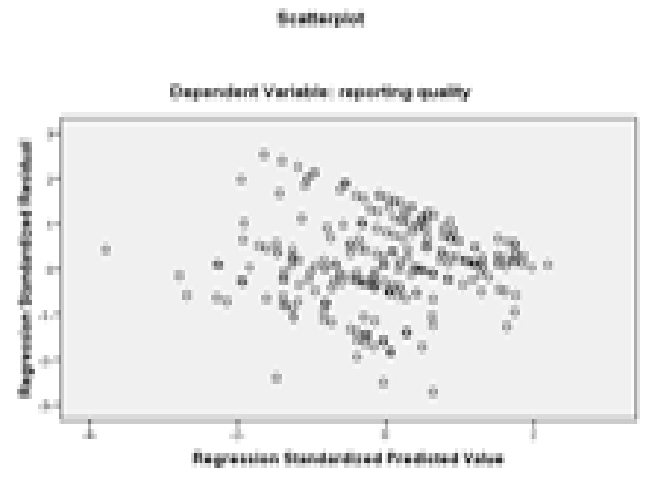

Figure 4. Result of scatterplot

The study used multiple regression to test the two previous basic assumptions (Hair et al., 2019). Consequently, the study used Criterion Validity, which the result of the diagnosis of the relationship between the independent variables with each other (Multicollinearity Diagnostics) appeared Low, less than 90\%, and this indicates that there is no internal association between the (IVs) (Multicollinearity); this statistical result is shown in the following table:

Table 2. Result of correlations

\begin{tabular}{llccc}
\hline & & Reporting quality & Performance & Composition \\
\hline $\begin{array}{l}\text { Pearson } \\
\text { Correlation }\end{array}$ & reporting & 1.000 & .438 & .295 \\
& quality & & & \\
& performance & .438 & 1.000 & .086 \\
& Composition & .295 & .086 & 1.000 \\
Sig. & reporting &. & .000 & .000 \\
$(1$-tailed) & quality & & & \\
& performance & .000 &. & .077 \\
& Composition & .000 & .077 &. \\
$\mathrm{~N}$ & reporting & 275 & 275 & 275 \\
& quality & & & \\
& performance & 275 & 275 & 275 \\
& Composition & 275 & 275 & 275 \\
\hline
\end{tabular}

In reality, VIF and TOL test also confirms that this relationship does not exist as it appeared in the following table:

Table 3. Result of multicollinearity

\begin{tabular}{lcc}
\hline Variables & $\begin{array}{c}\text { Collinearity Statistics } \\
\text { Tolerance }\end{array}$ & VIF \\
\hline (AC) Performance & 0.993 & 1.007 \\
(AC) Committee Composition & 0.993 & 1.007 \\
\hline
\end{tabular}

\subsection{Analysis of Study Data and Hypothesis Testing}

By testing the study hypotheses, reach an answer to the study's questions, and achieve its goals. To achieve this, the 
researchers used the following statistical methods:

\subsubsection{Multiple Regression Coefficients}

In order to test of the hypothesis, Multiple Regression was used, where the Interval Scale was used to measure the independent variables (AC Performance and AC Composition). Based on the preceding, the multiple regression coefficients was used to show the effect of (IVs) on the (DV), as shown in the table below:

Table 4. Result of Coefficients: The impact of independent variables on the dependent variable

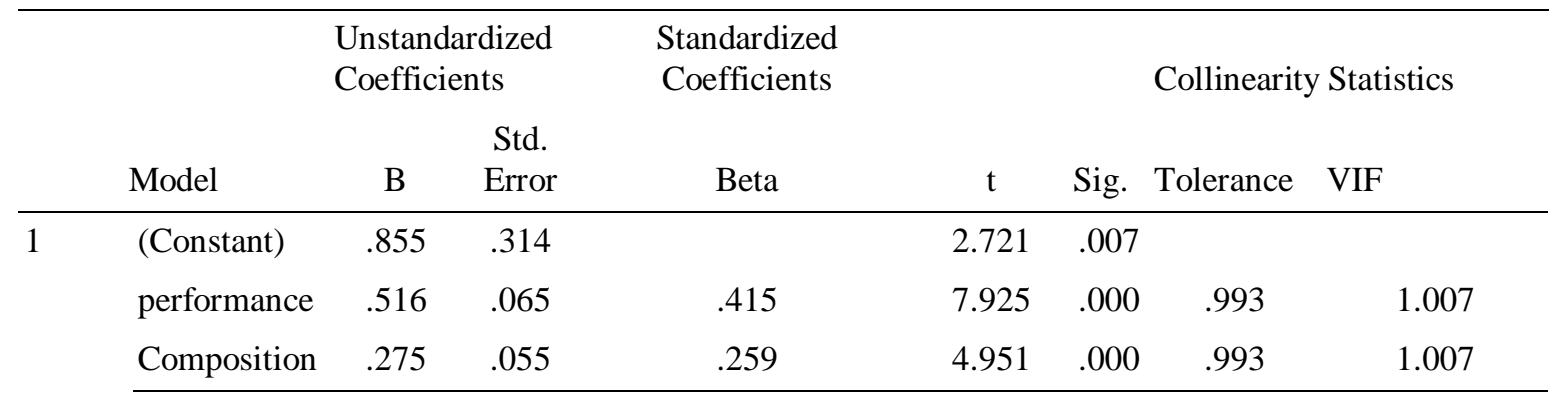

a. Dependent Variable: (FRQ)

From the context of the statistical analysis, the results indicate that all independent variables (AC Performance and AC Composition) have a positive impact on the dependent variable (FRQ) and all of them are statistically significant. In this way, the equation of regression it has become as follows: $Y=\beta_{1} .516+\beta_{2} .272+\varepsilon$

\subsubsection{Model Summary}

To evaluate $\mathrm{R}^{2}$ (R Square Coefficient), the researchers used a regression model summary as shown in the following table:

Table 5. Result of model summary

\begin{tabular}{lllll}
\hline Model & $\mathrm{R}$ & R Square & $\begin{array}{l}\text { Adjusted } \\
\text { Square }\end{array}$ & $\begin{array}{l}\text { R Std. Error of the } \\
\text { Estimate }\end{array}$ \\
\hline 1 & $.508^{\mathrm{a}}$ & .258 & .253 & .44633 \\
\hline
\end{tabular}

a. Predictors: (Constant), Composition, performance

b. DV: financial reporting quality

The regression model for this study is 0.258 . This indicates that the regression model shows the amount of variance in the dependent variable (quality of financial reports).

As for the following table, it refers to the ANOVA test to show the statistical significance of the regression model, as shown below:

Table 6. Result of Anova

\begin{tabular}{lcccccc}
\hline Model & & Sum of Squares & df & Mean Square & F & Sig. \\
\hline 1 & Regression & 18.882 & 2 & 9.441 & 47.392 & $.000^{\mathrm{a}}$ \\
& Residual & 54.186 & 272 & .199 & & \\
& Total & 73.068 & 274 & & & \\
\hline
\end{tabular}

a. Predictors: (Constant), Composition, performance

b. DV: financial reporting quality 
The results obtained by the researchers indicate that the ANOVA test showed that the study model was statistically significant .000 . This model found that the relationship of the (IVs) combined and the DV is a strong positive relationship that reached to $\mathrm{R}=.508$.

\subsubsection{Hypotheses Test}

$\mathrm{H}_{1}$ : there is a statistically significant impact of the (AC) performance on (FRQ) in manufacturing firms listed on the (ASE).

According to table number (4), each unit increases in the independent variable (performance of the audit committee), it is expected to increase by 0.516 in the dependent variable (quality of financial reports). The relationship direction is also positive between (AC) performance and (FRQ), as for the value of $\mathrm{T}=7.952$, Alpha is greater than .05. This indicates that the (AC) performance has influenced and contributes to the dependent variable, and it is statistically significant. Thus, we accept the alternative hypothesis that there is a statistically significant effect of the (AC) performance on the (FRQ) in Manufacturing Firms Listed on the (ASE).

$\mathrm{H}_{2}$ : Effect of Composition of (AC) on (FRQ) in manufacturing firms listed on (ASE).

Referring to Table No. (4), it was found that the factor of Composition of Audit Committee $=0.275$ at a statistically significant level $=0.00$. This refers that each unit increases in the independent variable (Composition of AC), it is expected to increase by $0.275 \mathrm{In}$ the dependent variable (FRQ). The signal of the variable is positive. The T-test also indicates that the value of $\mathrm{T}=4.951$; this means that the effectiveness of Composition of AC has a role and contributes to influencing the FRQ in manufacturing firms listed on ASE. Therefore, the results of this test made the researchers accept the alternative hypothesis. The result also indicates a statistically significant effect of the Composition of AC efficiency on the FRQ in manufacturing firms listed on ASE.

These findings support the results reported by Song and Windram (2004), who maintain that there are more audit committee meetings when stock performance is weak. Furthermore, it should be noted that these findings support the conclusion reached by Hsu (2007), who asserts that companies that are performing inadequately have a tendency to hold more meetings with the aim of keeping investors content in preference to improving firm value in regard to audit committee meetings

Sarens et al. (2009) showed that ACs disclosed that ACs seek relief in terms of the monitoring environment and internal monitoring out of internal auditors. Overall, aside from audit committee reviews relating to internal control and focusing on the control environment (Sarens, G., et.al, 2009), the outcomes are harmonious with the agency theory that audit committees may well alleviate agency problems resulting in reduced cost for an agency by ensuring the interests of the controlling owners and those of the company are consistent and subsequently improving the value of financial reporting.

One of the main aims of this particular study is to reveal the significance of the relationship between AC and value financial reports as CG mechanisms that are beneficial to organisations. This study stresses that audit committee reviews of IA proposals are essential aspects of corporate governance that result in a company improving it's the way it operates irrespective of the measures that are employed. It could be argued that regulators in Jordan (e.g. Capital Market Authority, CMA) inform audit committee to focus on this specific area in their supervisory role.

\section{Discussion}

The study showed that there is positive impact of audit committee performance and composition on financial reporting quality in industrial companies registered on the (ASE). This result complies with Eyenubo, Mudzamir, and Ali (2017) and Al-Shaer, et al., (2017). Therefore, audit committees enhance the financial position, earnings, and strengthen financials to industrial companies in Jordan. The performance and composition of audit committee are very important factors, in fact many previous studies supporting the importance of these factors because they confirm that the more performance and composition of audit committee the more FRQ. This study showed that the relationship between performance and composition of audit committee with FRQ were statistically significant and reached to $.516, .275$ respectively. This result will improve the FRQ and encourage the increase the investment in Jordan, this result may be positive to Jordanian economy and decrease the unemployment, also will lead to contributes in achieving the best incorporation to Jordanian capital market.

In contrast, the study of Umobong and Ibanichuka (2017) found that the audit committee failed to demonstrate the ability in its duties management Toward FRQ in Nigeria. But, (Ababneh, 2012; Bekhet and Matar, 2013) indicated that the audit committees help develop the FRQ, stop fraud, and increase dependability in FR, this result confirmed also by (Cohen et al., 2004). 


\section{Conclusion and Suggestions for Future Research}

In an attempt to develop the (FRQ), this study is based on the responses of (AC) members and financial managers as regards assessing the effectiveness of audit committees and the part they play in increasing the value and benefits of financial reporting. Hence, it is believed that future research should obtaining valuable information from external auditors. Research employing external auditors as evaluators of audit committee effectiveness and their impact on company performance will be crucial in confirming the results of the current study. ACs are responsible for guaranteeing the integrity and consistency of the control procedures over the financial transactions by way of carrying out various monitoring obligations that enable it to accomplish this objective. To be more specific, the impact of audit committees and their responsibilities as regards scrutinising the financial reporting process and external auditors were emphasised in the earlier literature. This is in accordance with the significance of the time and effort that ACs spend in the financial monitoring process. This is reinforced by the previous literature which highlights the part (ACs) play in the financial and monitoring process along with control system procedures. The reason for undertaking this piece of research is as a result of the noticeable gap in the current literature and the rather unsatisfactory evidence with regards to developing countries such as Jordan. The value of (FR) can be consistently related with (AC) characteristics for example financial expertise, committee size and independence. The presence of complex institutional shareholders may well encourage management to deliver financial reports that are of superior quality. In conjunction with audit committee composition and size, management could also be supportive of better financial reporting by way of other methods. For example, the board of directors could administer an ethics programme that is dedicated to openness.

It is important to mention that this research has only taken into account the composition and performance of the audit committee. For this reason, future research could take time to explore other governance systems, for instance boards of directors and internal audits, which may well have an influence on the effectiveness of corporate governance in Jordan. Additionally, this research has concentrated on the impact of internal corporate governance on the value of financial reporting. The model employed in this research was supposedly built on agency and institutional theory concerning internal corporate governance procedures (audit committees) and the value of financial reporting quality. To explain the determinants relating to the value of financial reporting more comprehensively, future research should take into consideration the effect of external corporate governance procedures. To be more specific, future research should investigate the influence of audit committee characteristics on audit quality and how audit quality could have an effect on the quality of financial reporting. In essence, it is crucial that the mediating effect of audit quality between audit committee characteristics and firm performance should be further explored, in particular in emerging countries. Likewise, with the aim of creating a model that explains maximum variance in firm performance, future research should seek to examine the effect of ownership structure on firm performance and consider to what extent this relationship is dependent on the degree of audit quality. Future research could also analyse other concepts that could be connected with internal governance mechanisms and the quality of financial reporting, for example stewardship, stakeholder and resource dependence theory. The important role of FRQ for policy makers in the capital market and Jordanian economy as it is the main source for making investment decisions by depending on FRQ in making their business choice. FRQ enables stockholders to depend on the financial statements (Gaynor, 2016; Shahzad et al., 2018). The results of the research emphasized that the audit committee as one of the main governance bodies and guidelines which organise and monitor the governance process. The findings have implications to the Jordanian monitoring business environments regarding FRQ. These results enable the policy maker to recognize the starting point for the enhancement that need to be prepared in the audit committee responsibilities and monitoring process overall which reflect on the FRQ.

\section{References}

Ababnih, M. (2012). The adequacy of the provisions of the Jordanian Companies Law No. 22 of 1997, as amended, to the achievement of corporate governance public shareholding in Jordan in light of the principles of international corporate governance. Studies Journal of Science and Law, 39(1).

Abbott, L. J., \& Parker, S. (2000). Auditor selection and audit committee characteristics. Auditing: A Journal of Practice \& Theory, 19(2), 47-66. https://doi.org/10.2308/aud.2000.19.2.47

Abbott, L. J., \& Parker, S. (2000b). The effects of audit committee activity and independence on corporate fraud. Managerial Finance, 26, 55-67. https://doi.org/10.1108/03074350010766990

Abdullah, W. Z. W., Ismail, S., \& Jamaluddin, N. (2016). The impact of board composition, ownership and CEO duality on audit quality: The malaysian evidence. Malaysian Accounting Review, 7(2). 
Adebayo, A. (2005). Financial reporting: an aid to efficient economic management in the public sector. The Nigerian Accountant, (1), 33.

Al-Akra, M., Ali, M. J., \& Marashdeh, O. (2009). Development of accounting regulation in Jordan. The International Journal of Accounting, 44(2), 163-186. https://doi.org/10.1016/j.intacc.2009.03.003

Al-Hajaya, K. (2019). The Impact of Audit Committee Effectiveness on Audit Quality: Evidence from the Middle East. International Review of Management and Marketing, 9(5), 1. https://doi.org/10.32479/irmm.8341

Alkilani, S. Z., Hussin, W. N. W., \& Salim, B. (2019). The Influence of Audit Committee Characteristics on Modified Audit Opinion in Jordan. Journal of Finance and Accounting, 7(3), 95-106. https://doi.org/10.11648/j.jfa.20190703.14

Alqatamin, R. M. (2018). Audit committee effectiveness and company performance: Evidence from Jordan. Accounting and Finance Research, 7(2), 48. https://doi.org/10.5430/afr.v7n2p48

Al-Shaer, H., Salama, A., \& Toms, S. (2017). Audit committees and financial reporting quality: Evidence from UK environmental accounting disclosures. Journal of Applied Accounting Research, 18(1), 2-21. https://doi.org/10.1108/JAAR-10-2014-0114

Al-Shaer, H., Salama, A., \& Toms, S. (2017). Audit committees and financial reporting quality. Journal of Applied Accounting Research. https://doi.org/10.1108/JAAR-10-2014-0114

Alzoubi, E. S. S. (2019). Audit committee, internal audit function and earnings management: evidence from Jordan. Meditari Accountancy Research. https://doi.org/10.1108/MEDAR-06-2017-0160

Ayinde, I. (2002). Audit committee: History and evolution. Presented at a National Seminar on Enhancing audit committee effectiveness, Organized by ICAN, Lagos.

Bajra, U., \& Čadež, S. (2018). Audit committees and financial reporting quality: The 8th EU Company Law Directive perspective. Economic Systems, 42(1), 151-163. https://doi.org/10.1016/j.ecosys.2017.03.002

Bajra, U., \& Cadez, S. (2018). The impact of corporate governance quality on earnings management: Evidence from European companies cross-listed in the US. Australian Accounting Review, 28(2), 152-166. https://doi.org/10.1111/auar.12176

Beasley, M. S., Carcello, J. V., Hermanson, D. R., \& Lapides, P. D. (2000). Fraudulent financial reporting: Consideration of industry traits and corporate governance mechanisms. Accounting Horizons, 14(4), 441-454. https://doi.org/10.2308/acch.2000.14.4.441

Beasley, M. S., Carcello, J. V., Hermanson, D. R., \& Neal, T. L. (2009). The audit committee oversight process. Contemporary Accounting Research, 26(1), 65-122. https://doi.org/10.1506/car.26.1.3

Beattie, V., Fearnley, S., \& Hines, T. (2013). Perceptions of factors affecting audit quality in the post-sox uk regulatory environment. Accounting and Business Research, 43(1), 56-81. https://doi.org/10.1080/00014788.2012.703079

Beest, F., Braam, G., \& Boelens, S. (2009). Quality of Financial Reporting: Measuring qualitative characteristics. NICE.

Bekhet, H. A., \& Matar, A. (2013). The influence of global financial crisis on Jordanian equity market: Vecm approach. International Journal of Monetary Economics and Finance, 6(4), 285-301. https://doi.org/10.1504/IJMEF.2013.059946

Biddle, G. C., Hilary, G., \& Verdi, R. S. (2009). How does financial reporting quality relate to investment efficiency? Journal of Accounting and Economics, 48(2-3), 112-131. https://doi.org/10.1016/j.jacceco.2009.09.001

Carcello, J. V., \& Neal, T. L. (2000). Audit committee composition and auditor reporting. The Accounting Review, 75(4), 453-467. https://doi.org/10.2308/accr.2000.75.4.453

Carcello, J. V., Hermanson, R. H., \& Mcgrath, N. T. (1992). Audit quality attributes: The perceptions of audit partners, preparers, and financial statement users. Auditing, 11(1), 1.

Cheung, E., Evans, E., \& Wright, S. (2010). An historical review of quality in financial reporting in Australia. Pacific Accounting Review, (0114-0582). https://doi.org/10.1108/01140581011074520 
Cohen, J. R., Hayes, C., Krishnamoorthy, G., Monroe, G. S., \& Wright, A. M. (2012) The effectiveness of sox regulation: An interview study of corporate directors. Behavioral Research in Accounting, 25(1), 61-87. https://doi.org/10.2308/bria-50245

Cohen, J., Krishnamoorthy, G., \& Wright, A. (2017). Enterprise risk management and the financial reporting process: The experiences of audit committee members, CFOs, and external auditors. Contemporary Accounting Research, 34(2), 1178-1209. https://doi.org/10.1111/1911-3846.12294

Cohen, J., Krishnamoorthy, G., \& Wright, A. M. (2002). Corporate governance and the audit process*. Contemporary Accounting Research, 19(4), 573-594. https://doi.org/10.1506/983M-EPXG-4Y0R-J9YK

Contessotto, C., \& Moroney, R. (2014). The association between audit committee effectiveness and audit risk. Accounting \& Finance, 54(2), 393-418. https://doi.org/10.1111/acfi.12010

Dechow, P. M., Sloan, R. G., \& Sweeney, A. P. (1996). Causes and consequences of earnings manipulation: an analysis of firms subject to enforcement actions by the SEC. Contemporary Accounting Research, 13, 1-36. https://doi.org/10.1111/j.1911-3846.1996.tb00489.x

Dechow, P., Sloan, R., \& Sweeney, A. (1995). Detecting earnings management. The Accounting Review, (70), 193-225.

DeFond, M. L., \& Jiambalvo, J. (1991). Incidence and circumstances of accounting errors. The Accounting Review, 66, 643-656.

Dezoort, F. (1997). An investigation of audit committees' oversight responsibilities. Abacus, 33(2), 208-227. https://doi.org/10.1111/1467-6281.00012

Downen, T. (2014, March 1). Defining and Measuring Financial Reporting Precision. Journal of Theoretical Accounting Research, 9(2), 21-57.

Eng, O., \& Johansson, J. (2016). Audit committees' influence on external audit quality and auditor independence: An analysis of listed swedish firms' committee effectiveness.

Engel, E., Hayes, R. M., \& Wang, X. (2010). Audit committee compensation and the demand for monitoring of the financial reporting process. Journal of Accounting and Economics, 49(1), 136-154. https://doi.org/10.1016/j.jacceco.2009.08.001

Eriabie, S. O., \& lzedonmi, F. (2016). Impact of audit committee attributes on financial reporting quality in Nigerian quoted companies. ICAN Journal of Accounting and Finance, 5(1).

Eyenubo, S. A., Mudzamir, M., \& Ali, M. (2017). Audit committee effectiveness of financial reporting quality in listed companies in Nigeria stock exchange. International Journal of Academic Research in Business and Social Sciences, 7(6). https://doi.org/10.6007/IJARBSS/v7-i6/3006

Garrow, N., \& Awolowo, I. (2018). Palmer \& Harvey: A case of governance and audit failure. Journal of Modern Accounting and Auditing, 14(7). https://doi.org/10.17265/1548-6583/2018.07.004

Gaynor, L. M., Kelton, A. S., Mercer, M., \& Yohn, T. L. (2016). Understanding the relation between financial reporting quality and audit quality. Auditing: A Journal of Practice \& Theory, 35(4), 1-22. https://doi.org/10.2308/ajpt-51453

Ghafran, C., \& O'sullivan, N. (2013). The governance role of audit committees: Reviewing a decade of evidence. International Journal of Management $\quad$ Reviews, $\quad 15(4), \quad 381-407$. https://doi.org/10.1111/j.1468-2370.2012.00347.x

Goodwin, J., \& Seow, J. L. (2000). Corporate governance in singapore: Perceptions of investors, directors, and auditors. Accounting and Business Review, 7(1), 39- 68.

Haka, S., \& Chalos, P. (1990). Evidence of agency conflict among management, auditors, and the audit committee chair. Journal of Accounting and Public Policy, 9(4), 271-292. https://doi.org/10.1016/0278-4254(90)90003-I

Ismail, H., Iskandar, T. M. \& Rahmat, M. M. (2016). Corporate reporting quality, audit committee and quality of audit. Malaysian Accounting Review, 7(1).

Jenkins, N. (2003). Auditor independence, audit committee effectiveness, and earnings management. Working paper, Washington University in St Louis. 
Jensen, M. C., \& Meckling, W. H. (1976). Theory of the firm: Managerial behavior, agency costs and ownership structure. Journal of Financial Economics, 3(4), 305-360. https://doi.org/10.1016/0304-405X(76)90026-X

Jonas, G. J., \& Blanchet, J. (2000). Assessing quality of financial reporting. Accounting Horizons, 14(3), 353-363. https://doi.org/10.2308/acch.2000.14.3.353

Jordan Securities Commission. (2010). Corporate Governance Code for Shareholding Companies Listed on the Amman Stock Exchange. Retrieved January 10, 2016, from www.jsc.gov.jo

Kamel, H., \& Elkhatib, S. (2013). The perceptions of audit committees' role in an emerging market: The case of Egypt. Journal of Economic and Administrative Sciences, 29(2), 85-98. https://doi.org/10.1108/JEAS-09-2013-0028

Karaibrahimoglu, Y. Z. (2013). Is corporate governance a determinant of auditor choice?-evidence from turkey/kurumsal yönetim denetçi seçiminde belirleyici midir?-türkiye'den bulgular. Ege Akademik Bakis, 13(2), 273. https://doi.org/10.21121/eab.2013219494

Kikhia, H. Y. (2014). Board characteristics, audit committee characteristics, and audit fees: Evidence from jordan. International Business Research, 7(12). https://doi.org/10.5539/ibr.v7n12p98

Kipkoech, S. R., \& Rono, L. (2016). Audit committee size, experience and firm financial performance. Evidence Nairobi securities exchange, Kenya. Research Journal of Finance and Accounting, 7(15).

Klein, A. (2002a). Audit committee, board of director characteristics and earnings management. Journal of Accounting and Economics, 33, 375-400. https://doi.org/10.1016/S0165-4101(02)00059-9

Lee, H. Y., Mande,V., \& Ortman, R. (2004). The effect of audit committee and board of director independence on auditor resignation. Auditing: A Journal of Practice \& Theory, 23(2), 131-146. https://doi.org/10.2308/aud.2004.23.2.131

Majiyebo, O. J., Okpanachi, J., Nyor, T., Yahaya, O. A., \& Mohammed, A. (2018). Audit committee independence, size and financial reporting quality of listed Deposit Money Banks in Nigeria. IOSR Journal of Business and Management, 20(2), 40-47.

Marashdeh, Z. M. S. (2014). The effect of corporate governance on firm performance in Jordan. University of Central Lancashire.

McMullen, D. A. (1996). Audit committee performance: an investigation of the consequences associated with audit committees. Auditing: A Journal of Practice and Theory, 15, 87-103.

Means, G. C. (1941). The structure of the American Economy. Parti. Basic characteristics.

Menon, K., \& Williams, J. D. (1994). The use of audit committees for monitoring. Journal of Accounting and Public Policy, 13(2), 121-139. https://doi.org/10.1016/0278-4254(94)90016-7

Moses, T., Ofurum, C. O., \& Egbe, S. (2016). Audit committee characteristics and quality of financial reporting in quoted Nigerian banks. International Journal of Advanced Academic Research, 2(5), 1-8.

Nazari, H., \& Soukhakyan, I. (2020). Characteristics of the Chairman of Audit Committee and Timely Financial Reporting. Journal of Knowledge Accounting, 11(3), 131-165.

Nwanyanwu, L. A. (2013). Financial reporting and organizational liquidity in Nigeria: the accounting bases perspective. Research Journal of Finance and Accounting, 4(16).

Peasnell, K. V., Pope, P. F., \& Young, S. (2001). The characteristics of firms subject to adverse rulings by the financial reporting panel. Accounting and Business Research, 31, 291-311. https://doi.org/10.1080/00014788.2001.9729621

Rainsbury, E. A., Bradbury, M., \& Cahan, S. F. (2009). The impact of audit committee quality on financial reporting quality and audit fees. Journal of Contemporary Accounting \& Economics, 5(1), 20-33. https://doi.org/10.1016/j.jcae.2009.03.002

Sarens, G., De Beelde, I., \& Everaert, P. (2009). Internal audit: A comfort provider to the audit committee. The British Accounting Review, 41(2), 90-106. https://doi.org/10.1016/j.bar.2009.02.002

Shahanif, H. (2017). The moderating effect of audit quality on audit committee and financial reporting quality in Malaysia. Doctoral dissertation, Universiti Utara Malaysia. 
Shatnawi, S., Hanefah, M., Adaa, A., \& Eldaia, M. (2019). The Moderating Effect of Enterprise Risk Management on the Relationship between Audit Committee Characteristics and Corporate Performance: A Conceptual Case of Jordan. International Journal of Academic Research Business and Social Sciences, 9(5). https://doi.org/10.6007/IJARBSS/v9-i5/5849

Soliman, M. M., \& Ragab, A. A. (2014). Audit committee effectiveness, audit quality and earnings management: An empirical study of the listed companies in Egypt. Research Journal of Finance and Accounting, 5(2), 155-166. https://doi.org/10.2139/ssrn.2315355

Song, J., \& Windram, B.(2004). Benchmarking audit committee effectiveness in financial reporting. International Journal of Auditing, 8(3), 195-205. https://doi.org/10.1111/j.1099-1123.2004.00090.x

Tang, Q., Chen, H., \& Lin, Z.(2016). How to measure country-level financial reporting quality?. Journal of Financial Reporting and Accounting. https://doi.org/10.1108/JFRA-09-2014-0073

Turley, S., \& Zaman, M. (2004). The corporate governance effects of audit committees. Journal of management and governance, 8(3), 305-332. https://doi.org/10.1007/s10997-004-1110-5

Umobong, A. A., \& Ibanichuka, E. A. L. (2017). Audit committee attributes and financial reporting quality of food and beverage firms in Nigeria. International Journal of Innovative.

Vinten, G., \& Lee, C. (1993). Audit committees and corporate control. Managerial Auditing Journal, 8(3). https://doi.org/10.1108/02686909310036232

Watts, R. L., \& Zimmerman, J. L. (1978). Towards a positive theory of the determination of accounting standards. Accounting review, 112-134.

Willekens, M. (2008). Effects of external auditing in privately held companies: Empirical evidence from Belgium. Working paper series.

Wu, C. Y. H., Hsu, H. H., \& Haslam, J. (2016). Audit committees, non-audit services, and auditor reporting decisions prior to failure. The British Accounting Review, 48(2), 240-256. https://doi.org/10.1016/j.bar.2015.03.001

Yurisandi, T., \& Puspitasari, E. (2015). Financial Reporting Quality-Before and After IFRS Adoption Using NiCE Qualitative Characteristics Measurement. Procedia-Social and Behavioral Sciences, 211, 644-652. https://doi.org/10.1016/j.sbspro.2015.11.091

Zaman, M., Hudaib, M., \& Haniffa, R. (2011). Corporate governance quality, audit fees and non-audit services fees. Journal of Business Finance \& Accounting, 38(12), 165-197. https://doi.org/10.1111/j.1468-5957.2010.02224.x

\section{Copyrights}

Copyright for this article is retained by the author(s), with first publication rights granted to the journal.

This is an open-access article distributed under the terms and conditions of the Creative Commons Attribution license (http://creativecommons.org/licenses/by/4.0/). 